Check for updates

Cite this as: $B M J 2020 ; 370: \mathrm{m} 3372$ http://dx.doi.org/10.1136/bmj.m3372 Published: 28 August 2020

\section{A covid-19 laboratory for Jersey-in a shipping container}

In this feature (BMJ 2020;370:m3336, doi:, published 27 August 2020) we have corrected the definition of RT-PCR (reverse transcription, not real time,

polymerase chain reaction). We have also updated some of the numbers: 2000 (not 500) tests a day, with results available within 24 (not 30) hours. 